\title{
Beyond National Systems, Towards a 'Gig Economy'? A Research Agenda for International and Comparative Employment Relations
}

\author{
Chris F. Wright ${ }^{1} \cdot$ Nick Wailes $^{2}$ • Greg J. Bamber ${ }^{3,4}$. \\ Russell D. Lansbury ${ }^{1}$
}

Published online: 1 December 2017

(C) The Author(s) 2017. This article is an open access publication

\begin{abstract}
This journal (Volume 29, Issue 3, 2017) included four review essays that focussed on the 6th edition of the book International and Comparative Employment Relations: National Regulation, Global Changes (Bamber et al. 2016). This article reflects on these essays. It begins to develop a novel multi-scalar analytical framework for comparing employment relations internationally, which includes the influence of the institutional dynamics of industrial sectors and global production networks as well as national systems. It also discusses three aspects of the gig economy. Further it proposes a research agenda that would look beyond Varieties of Capitalism approaches, to embrace a more dynamic and diverse array of regulatory systems, including the gig economy and other developments in the world of work and employment relations.
\end{abstract}

Keywords Gig economy - Global production networks · International and comparative employment relations · Liberal market economies · Coordinated market economies · Varieties of capitalism

\section{Introduction}

The September 2017 issue of this journal included four review essays by Mathieu Dupuis (Cornell University/Université de Montréal); Teresa Shuk-ching Poon (Open University of Hong Kong) and Catherine W. Ng (Hong Kong Polytechnic University); Sek-hong Ng, (University of

\section{Greg J. Bamber}

gregbamber@gmail.com

1 University of Sydney Business School, University of Sydney, Sydney, Australia

2 UNSW Business School, UNSW, Sydney, Australia

3 Monash Business School, Monash University, Melbourne, Australia

4 Newcastle University Business School, Newcastle University, Newcastle upon Tyne, UK 
Hong Kong); and Ngan Collins (RMIT University). We are honoured that these talented people with much international expertise in employment relations (ER) devoted some of their valuable time to engage with the ideas in the 6th edition of our book International and Comparative Employment Relations: National Regulation, Global Changes (Bamber et al. 2016). We are much obliged to Victor Devinatz (Illinois State University) and the Employee Responsibilities and Rights Journal for commissioning these essays and for inviting us also to contribute this article.

The essays include the kind of reflections on international and comparative employment relations research that our book aims to stimulate. Several important themes are raised in more than one of the four essays. Therefore, this article addresses some of these themes rather than re-visiting each of the essays in detail. The 6th edition of our book has an emphasis on globalization and comparative theories, including concepts of convergence. Experts examine the economic, historical, legal, social and political context of ER in 12 country chapters. The book concludes with an account of the forces shaping and regulating ER internationally, with a focus on the implications of these forces for relevant theories, in particular the 'Varieties of Capitalism' approach (Hall and Soskice 2001). Since it was proposed, this approach has been influential in international and comparative ER scholarship. In this article, we build on these ideas and engage with some of the insights offered in the four essays to outline a research agenda for future international and comparative ER scholarship. We emphasize a need to move beyond a focus on national systems as the main unit of analysis, to also consider the importance of sectoral and global institutions, as well as the 'gig' economy.

\section{The Varieties of Capitalism Approach}

Our book includes inter-disciplinary discussions of the role of ER actors and institutions as well as contemporary issues and trends in 12 countries. Several book reviews have identified an advantage of our book is that it presents its discussions in a consistent analytical approach, which facilitates understanding of international and comparative ER (e.g. Leggett 2017). As a point of departure, we use the two 'ideal types' of the Varieties of Capitalism (VoC) approach. In brief, these two types are: first, liberal market economies (LMEs), where employers tend to rely upon market forms of coordination to determine pay and develop skills; and, second, coordinated market economies (CMEs), where employers tend to organize their activities through nonmarket mechanisms, such as multi-employer collective bargaining (Hall and Soskice 2001).

We draw on evidence from 12 countries. These include four English-speaking countries: the United Kingdom (UK), the United States of America (USA), Canada and Australia, which are characterized as LMEs. We also examine four continental European countries: Germany, Denmark, Italy and France, which to varying extents might be seen as CMEs. Four Asian market economies are also included: Japan and Korea - which may also be classified as CMEs - as well as China and India. The latter two large Asian emerging economies are difficult to categorize using the VoC approach.

A challenge for those of us who are interested in international and comparative studies in any field is that we can gather mountains of facts about different countries. How can we start to make sense of similarities and differences between them? What variables provide a meaningful basis for comparison? The VoC approach is influential and well known. We use this approach as a useful starting point for analysis of international and comparative ER. Several commentators point out that the VoC categories have only a 
limited relevance to many countries, e.g. emerging economies, and that there is considerable diversity of the ER systems within these LME and CME categories (Crouch 2005).

The VoC categories are not static. We can identify examples of countries oscillating between the two categories. For example, until the 1980s arguably the UK displayed elements of the CME model, such as multi-employer collective bargaining in many industrial sectors. After the election of the Thatcher government in 1979, the UK moved closer to the LME ideal type (Howell 2003). However, in the context of prolonged economic stagnation in the UK following the global economic recession of 2008-09, there are early indications that employers and unions in a few industries in the UK may be moving back towards CME-type arrangements for regulating ER (Heery et al. 2017).

This shows that rather than national systems alone, other factors, in this case the dynamics of particular sectors and their interaction with national regulations, can be relevant for understanding ER in a comparative context. Nevertheless, an important advantage of the VoC approach is that we can use it to begin to make comparisons between countries. This can serve as a 'springboard' that might help us to develop more satisfactory approaches such as a multi-level analysis of ER encompassing national systems as well as other relevant factors at the sectoral and global levels.

\section{Towards a Multi-Level Analysis of Comparative Employment Relations}

Several of the essays (e.g. Collins 2017; Dupuis 2017; $\mathrm{Ng} 2017$ ) and other commentators point to a need for a multi-level analysis of ER which takes into account the global, national and sectoral levels of ER across various countries and the interaction between them. We address this need by developing Fig. 1, which provides an illustration of three institutional spheres and their modes of interaction. We suggest that that these three spheres are worth focusing on when analyzing and comparing ER in different contexts.

\section{National Institutions}

National institutions play an important role in influencing the strategic choices of employers, unions, policymakers and other ER actors. Distinct national 'models' have been identified in certain countries, which ER actors in other countries have sought to emulate or avoid. One

Fig. 1 Institutional spheres influencing employment relations arrangements

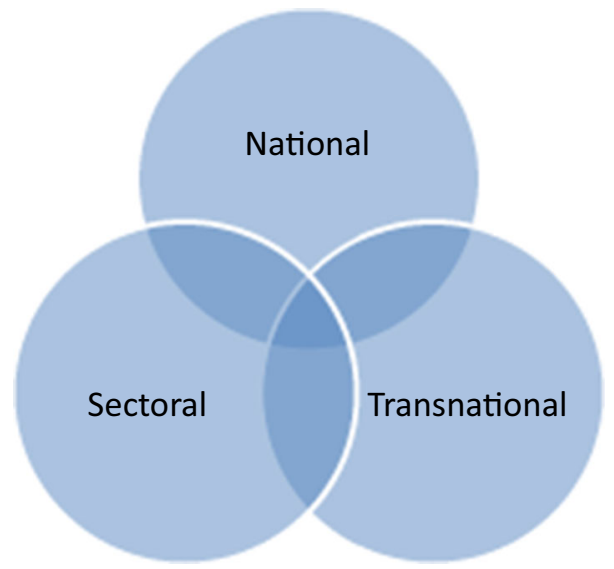


example is the Danish system of 'flexicurity', which has been seen as a potential model for other economies (Madsen et al. 2016).

A national-systems lens has been used to explain similarities and differences in employer preferences and employment regulation. These include, among other things, the gendered nature of labor markets, employee participation, job quality, vocational training systems, labor immigration policies, collective bargaining and union membership density (Martin and Bamber 2004; Frege and Kelly 2004; Estevez-Abe 2006; Harcourt and Wood 2007; Lansbury and Wailes 2008; Bamber et al. 2009; Goergen et al. 2012; Wright 2012; Frege and Godard 2014). National institutions still matter, then, and have a continuing impact on strategic choices of ER actors including the form of employment, the determination of pay and other working conditions, and how their interests are represented.

However, the potential for national models as a dominant reference point for allowing us to explain comparative ER may be diminishing. This is evident in relation to earnings inequality. Various factors influence earnings inequality, but systems of pay determination are crucial due to their role in distributing wages relative to profits. According to Baccaro and Pontusson (2016), during the period from 1975 to 1995, rising earnings inequality was especially evident among LMEs, such as the USA and the UK, in part because of the strength of managerial prerogative over pay determination in these countries. By contrast, in CMEs such as Finland, where unions and the state played a prominent role in pay determination, earnings inequality declined. However, in the period since the mid-1990s earnings distribution outcomes have not conformed to VoC patterns. LMEs such as Ireland and the UK (as well as several CMEs) have experienced declining or stabilisation of inequality trends. This contrasts with a relative widening of earnings inequality among CMEs such as Norway, Denmark and Germany (in addition to LMEs such as the USA and Australia) since 1995.

Changes in how ER arrangements are coordinated is another reason why the utility of a national systems approach may be diminishing. There is still much cooperation among employers in CMEs such as Denmark and in the German manufacturing sector over pay determination and skill formation. However, in Germany the private-services sector and small and medium-sized enterprises have opted out of sectoral bargaining in favor of enterprisebased determination typically without unions (Keller and Kirsch 2016; Madsen et al. 2016). 'Lifetime employment', traditionally a hallmark of the Japanese system, has come under pressure from changing patterns of corporate governance that have adopted shareholderdriven models to a greater extent than hitherto. This has led to a growth in non-standard and precarious employment (Suzuki et al. 2016). Similar outcomes can be seen in South Korea (Lee 2016).

Such outcomes give credence to the criticism that the VoC approach does not contain enough variety (Allen 2004; Schmidt 2002) and is too static to account for change within national systems (Deeg and Jackson 2007). They also lend support to Baccaro and Howell's argument that national systems 'are being transformed in a common [liberal] direction' (Baccaro and Howell 2011, 522; see also Colvin and Darbishire 2013). However, drawing on our analysis of 12 national systems (Bamber et al. 2016), we conclude that this trend has not been uniform in either its speed or its scope. Rather, the evidence seems consistent with Thelen's (2014, p. xx) claim that 'common liberalizing pressures ... are being channelled in different ways.' We would argue that this partly reflects the inherent characteristics of certain sectors that produce 'dominance effects' (Edwards et al. 2013; Pudelko and Harzing 2008; Smith and Meiksins 1995) in influencing the strategic choices of ER actors. 


\section{Sectoral Institutions}

Thelen argues that a significant limitation of the $\mathrm{VoC}$ approach relates to its extrapolation of the specific preferences of manufacturing employers to be the coordination preferences of all employers. The structural shift from manufacturing to services that has occurred in nearly all developed economies 'has upset previous political dynamics because both firms and workers in these emerging sectors have interests that are very different from their counterparts in traditional manufacturing', according to Thelen (2014, 25). Manufacturing employers tend to prefer CME-type arrangements, such as long-term employment relationships and skill regimes focused on the development of enterprise and industry-specific skills. In contrast, servicesector employers tend to favor general and portable skill regimes and arrangements that facilitate more 'flexible' employment relationships (see also Batt et al. 2009; Bechter et al. 2012; Caviedes 2010; Katz and Darbishire 2000; Wright 2017).

In some countries, shifts in the sectoral composition of the national labor market have had an influence on the dominant preferences of employers. In Australia, for instance, there has been a shift away from non-market coordination of skill formation and pay determination, which until relatively recently was favoured by manufacturing employers. Nevertheless, reflecting their relative decline, the influence of manufacturing employers over national ER regulation has waned. By contrast, there is a preference for labor-market deregulation among employers in the private-services and resource sectors, which have both experienced much growth in the twenty-first century. This shift in the dominant employer coordination preferences has served to embed the 'liberal' market (LME) features of Australia's ER system (Wright and Lansbury 2014).

In Germany, while manufacturing, finance and public sector employers continue to prefer non-market coordination, as mentioned above private-services sector and small-business employers are increasingly preferring market coordination. The growth in private-service sector employment is arguably producing a transformational shift in the post-1945 'German model' of employment relations (Bechter et al. 2012; Hassel 2014). More generally, this trend illustrates the extent to which sectoral issues, such as the mix of industries in a particular national economy, can influence the strategic choices of ER actors independently of nationallevel institutional arrangements.

Sector-based logics, then, may cut across national systems, thus enabling increased diversity in ER arrangements within countries. Without discounting the influence of national systems, the role of sector-level variables - such as pay determination and skill formation arrangements, technology, the organization of production and product market regulations should be given greater weight as a potential influence of ER patterns (Bechter et al. 2012; Katz and Darbishire 2000).

\section{Transnational Institutions}

At least one of the essays argues that the field of international and comparative ER must assess the impact of the global level (Dupuis 2017). Another salient criticism of the VoC approach, then, relates to its neglect of international factors. As Hancke et al. $(2007,7)$ point out, the VoC approach has a tendency to treat "nation-states as "hermetically sealed" and [to] neglect the linkages between them'. Indeed, Hall and Soskice's (2001) VoC approach assumes that economies are relatively closed, so that institutions have homogeneous effects within national boundaries. Consequently the $\mathrm{VoC}$ approach downplays or 
overlooks the role played by international factors. However, the growth of multilateral forms of governance over the past decade or so indicates that the influence of transnational factors on actors' strategic choices needs to be included more comprehensively in international and comparative ER analysis (Meardi and Marginson 2014).

'Private' forms of transnational governance, such as the commercial policies and practices of multinational enterprises (MNEs), are also increasingly important for understanding the strategic choices of ER actors (Katz and Wailes 2014). MNEs have extended their commercial presence and power by creating subsidiaries offshore and through global production networks that engage suppliers located in other countries, in many cases enabling MNEs to reduce labor costs (Lakhani et al. 2013; Locke et al. 2013; Wright and Kaine 2015). For example, many US enterprises have offshored parts of their activities to emerging economies (Katz and Colvin 2016). Japanese manufacturers have relocated many jobs to offshore subsidiaries (Suzuki et al. 2016). In China, employment agencies engaging low-paid workers have benefited from widespread downsizing among state-owned enterprises and of significant migration of workers from rural to urban areas (Cooke 2016).

In Denmark, the EU Posted Workers Directive to an extent has enabled employers to circumvent collective agreements by hiring workers through subcontractors registered in Central and Eastern European countries with lower pay levels (Madsen et al. 2016). This has allowed employers to gain similar cost advantages that might otherwise have been achieved through offshoring. Outsourcing and offshoring often entail a shift to more market-oriented relationships between a lead enterprise and a supplier enterprise governed by commercial imperatives (see Gereffi et al. 2005; Marchington et al. 2005; Wright 2016). Therefore, even in CMEs, increased use of outsourcing and offshoring has produced more 'market' oriented ER arrangements.

Lastly, various international institutions can directly influence the strategic choices of ER actors. For example, the conventions of the International Labour Organization (ILO) are reflected in the laws of countries that ratify them. It is also increasingly common for ILO conventions to serve as benchmarks for voluntary instruments relating to ER arrangements of offshore suppliers and subsidiaries, such as MNEs' codes of conduct and global framework agreements between global union federations and MNEs (Ryder 2015). These transnational instruments have helped partly to address the problem of weak regulation of labor standards in global production networks (Ruggie 2013). Nevertheless, national institutions and sectoral institutions also influence the impact of such transnational instruments on local ER arrangements (Locke et al. 2013).

\section{Institutional Intersections}

We have discussed the role of institutions at the national, sectoral and transnational levels and the ways these influence ER arrangements. These institutions may have a more dominant impact in certain scenarios and may function relatively discretely from institutions operating at other scales. For instance, the systems of 'awards' which influences workplace pay determination in Australia or flexicurity which influence employer decisions relating to hiring and firing in Denmark might be seen primarily as national ER institutions that transnational and sectoral institutions have played little role in creating and sustaining. Other strategic choices might be a product of a combination of two institutional spheres, but not the third. For example, Appelbaum et al. (2010) explore the interplay between national regulation and sectoral characteristics in their study of low-paid work in six developed economies. They find that sectoral characteristics appear to be more important than national regulatory frameworks for understanding ER arrangements in the hotel industry, for 
instance, but that in the retail industry the influence of national institutions is stronger. In other cases, national, sectoral and transnational institutions may all impact ER processes or outcomes. For example, the nature of work organization in the automotive industry is influenced by the preferences of MNEs who own the production plants, sectoral norms regarding production techniques, and factors pertaining to local ER including skill-development arrangements, the organization of labor, and employment regulations (Wailes et al. 2008). There is considerable scope for future research to examine the different ways that distinct institutional spheres intersect to influence ER arrangements.

\section{Development of the 'Gig' Economy}

Appropriately, at least two of the essays (Poon and Ng 2017; Ng 2017) highlight relatively recent economic developments that are increasingly impacting ER and work organization such as the 'gig' economy, also known as the 'sharing' economy or 'platform' businesses. The temporary work associated with platforms such as Uber and Airbnb, which generally do not see workers as 'employees', is becoming more widespread around the world. Workers engaged on these platforms are usually not covered by most employment laws, nor by all of the superannuation benefits, sick leave, holiday pay and the workplace health and safety regulation that applies to most employees. Space here does not permit a detailed discussion; nonetheless, we offer three observations about developments in the gig economy and implications for the comparative study of ER.

First, while highly visible, the gig economy is still relatively small in most economies. Estimates vary widely. In a 2016 report, McKinsey Global Institute used survey evidence to estimate that up to $20 \%$ of the adult workforce in the US and Europe were involved in some form of independent work (Manyika et al. 2016). This, however, was based on a very broad definition of independent work. Analysis by US Treasury officials of tax returns and social security returns found that in 2014 less than $0.7 \%$ of the US workforce could be classified as working in the gig economy (Jackson et al. 2017). There are significant differences in estimates of the size of the gig economy, but most analyses suggest that it is growing rapidly. Although it may take some time for a clear picture to emerge, it is important for ER scholars to pay attention to the rise of the gig economy and its interaction with other forms of employment.

A second observation is that the gig economy is complex and covers a broad range of industries and occupations. In particular, some of the platforms make it possible to access lowcost and relatively 'unskilled' labor (like Uber, Taskrabbit, and the former Homejoy, to name just a few). Nevertheless, there are also those that provide highly skilled and specialized workers with direct access to work without them necessarily having to be associated with an employer. Examples of these type of platforms include Topcoder, Expert360 and Kaggle. Despite the similarities in the underlying technology that powers them, there are very different labor-market dynamics taking place on these platforms. Expert360, an Australian marketplace for consultants, for example, makes it possible for highly specialized consultants to capture a greater percentage of the fees associated with the delivery of a professional service than would apply if they worked through a large enterprise. For these types of highly skilled workers, the issues they face are whether the platforms can deliver the same volume and quality of highly paid work that they would otherwise get through a larger enterprise and whether the higher payoffs offset the potential variability of demand. These are the same types of decisions that, for example, lawyers have long had to make in deciding whether to remain in a large firm or establish their own practice. The main change is that these platforms may lower the costs and risks of setting up as an 'independent expert' and make it easier to access work. 
Perhaps more interesting for ER scholars are the platforms that provide organizations and individuals access to low-skilled labor on an on-demand basis. On such platforms the potential for exploitation is higher and the implications for other forms of employment are more dramatic. Increasingly, there is a debate about whether the independent contractors on these platforms are truly independent or whether they can be more appropriately defined as employees. Sprague (2015), for example, argues that assessment of whether a contractor on a platform like Uber or Deliveroo is an employee should focus not on whether the employee is dependent on the platform, but rather whether the business model of the platform depends on the existence of the contractor. In the US, where the gig economy is the most developed, courts are increasingly accepting such arguments and placing constraints of the extent to which these types of models can be used to circumvent employment protections. Threats of legal action by contractors who claimed that they were employees led to the decision to close Homejoy in 2015. There are more legal cases being brought against gig economy platforms in the US and in other countries (Farivar 2015; Sanders and Pattison 2016).

This leads to a third observation. While many of the on-demand platforms have global ambitions, their spread and impact on employment conditions vary significantly across countries and are influenced not only by local market conditions, but also by national regulations and institutions. Just because a gig economy platform works in one market does not mean that it can be reproduced in all other markets. Local competitors that are better adjusted to local market conditions may be more successful than 'transplants' originating abroad. For instance, despite investing billions of dollars in China, the world's largest ride-hailing market, Uber, was defeated by the local regulatory context. In 2016 Uber sold its business there to a Chinese rival Didi Chuxing (Kuo et al. 2016). Moreover, in Indonesia, Uber has been relatively unsuccessful in competing with the local taxi industry. The local gig-economy startup Go-Jek that focusses on motor scooters rather than private cars has been much more successful in the Indonesian market (Wailes 2016). Go-Jek's impact has been to displace private-scooter drivers in the informal economy rather than to affect directly the taxi drivers in the formal economy. Uber has had mixed success in rolling its business model out across countries and its inability to overcome regulatory barriers in new markets is constraining its growth (Murad and Hook 2015). From a comparative ER perspective, it is interesting that national and local regulations and institutions may shape how the gig economy develops across countries.

Our observations show that the rise of the gig economy is a significant development and an important area for those interested in international and comparative ER research. The essay authors who highlighted this relatively new area deserve credit; in the next edition of the book, we look forward to focusing on this area in more detail. It remains to be seen whether the ways in which the gig economy develops and its consequences in terms of work organization can be explained in terms of the concepts discussed in the 6th edition or whether we will need to develop new explanatory models.

\section{Conclusions}

The VoC framework remains an important starting point for comparing the differential impact of national regulation on the strategic choices of ER actors. However, the increased importance of global production networks, international institutions, sectoral dynamics and the gig economy for understanding ER in a comparative context suggests the need to develop an analytical framework that moves beyond the prevailing focus on national systems. In this article, we have begun to 
develop a novel framework that includes the influence of distinct institutional dynamics of sectors and global production networks as well as national systems. While the framework in this article is largely descriptive at this stage, there is potential for future research to build on theories of path dependency (Streeck and Thelen 2005; Thelen 2014) and dominance effects (Edwards et al. 2013; Pudelko and Harzing 2008; Smith and Meiksins 1995). Such research should help to explain the circumstances in which certain types of ER, such as more market-oriented arrangements or more coordinated arrangements, may emerge at workplaces in certain scenarios. We propose an agenda for the future that would look beyond national systems approaches, to embrace a more dynamic and diverse array of regulatory systems, including the gig economy and other developments in the world of work and ER. Such continuing developments help to make this field so interesting and fruitful for researchers.

To understand ER around the world, there is always more to learn about the varieties of national institutions and practices. However, as we learn, we should try to adopt a fine-grained, contextual approach to analyzing international and comparative ER. This would be facilitated by adopting a multi-scalar analytical framework for comparing ER systems internationally. We have started to foreshadow such a framework in this article.

Acknowledgements This article builds on the book International \& Comparative Employment Relations: National Regulation, Global Changes (Bamber et al. 2016). Many thanks to all those who helped to improve the book, including a range of advisors and referees (too many to list here) and contributors (William Brown, Foreword; Jeremy Waddington, UK; Harry C. Katz and Alexander J.S. Colvin, USA; Daphne G. Taras and Scott Walsworth, Canada; Lucio Baccaro and Valeria Pulignano, Italy; Patrice Laroche, France; Berndt Keller and Anja Kirsch, Germany; Jørgen Steen Madsen, Jesper Due and Søren Kaj Andersen, Denmark; Hiromasa Suzuki, Katsuyuki Kubo and Kazuya Ogura, Japan; Byoung-Hoon Lee, South Korea; Fang Lee Cooke, China; Anil Verma and Shyam Sundar, India). Most of the contributors also made free videos to complement the book; see: study.sagepub.com/node/37463/instructor-access. We are grateful to Chang Kai, Renmin University/Capital University of Economics and Business, and Fang Lee Cooke, Monash University, for leading the adaptation of the 6th edition into a Chinese version in Mandarin, published by China Labour \& Social Security Publishing House (www.class.com.cn). We are also grateful to several conference organizers and participants who allowed us to discuss with them earlier versions of this article and who provided helpful comments.

Open Access This article is distributed under the terms of the Creative Commons Attribution 4.0 International License (http://creativecommons.org/licenses/by/4.0/), which permits unrestricted use, distribution, and reproduction in any medium, provided you give appropriate credit to the original author(s) and the source, provide a link to the Creative Commons license, and indicate if changes were made.

\section{References}

Allen, M. (2004). The varieties of capitalism paradigm: Not enough variety? Socio-Economic Review, 2, 87-108. Appelbaum, E., Bosch, G., Gautié, J., Mason, G., Mayhew, K., Salverda, W., Schmitt, J., \& Westergaard-Nielsen, N. (2010). Introduction and overview. In J. Gautié \& J. Schmitt (Eds.), Low-wage work in the wealthy world (pp. 1-32). New York: Russell Sage.

Baccaro, L., \& Howell, C. (2011). A common neoliberal trajectory: The transformation of industrial relations in advanced capitalism. Politics \& Society, 39, 521-563.

Baccaro, L., \& Pontusson, J. (2016). Rethinking comparative political economy: The growth model perspective. Politics \& Society, 44, 175-207.

Bamber, G. J., Gittell, J. H., Kochan, T. A., \& von Nordenflycht, A. (2009). Up in the air: How airlines can improve performance by engaging their employees. Ithaca: Cornell University Press.

Bamber, G. J., Lansbury, R. D., Wailes, N., \& Wright, C. F. (Eds.). (2016). International and comparative employment relations: National regulation, global changes, 6th edition. London / Sydney: SAGE / Allen \& Unwin.

Batt, R., Holman, D., \& Holtgrewe, U. (2009). The globalization of service work: Comparative institutional perspectives on call centers. Industrial and Labor Relations Review, 62, 453-488.

Bechter, B., Brandl, B., \& Meardi, G. (2012). Sectors or countries? Typologies and levels of analysis in comparative industrial relations. European Journal of Industrial Relations, 18, 185-202. 
Caviedes, A. A. (2010). Prying open fortress Europe: The turn to sectoral labor migration. Lanham: Lexington. Collins, N. (2017). A short essay on International and Comparative Employment Relations. Employee Responsibilities and Rights Journal, 29, 173-174.

Colvin, A. J. S., \& Darbishire, O. (2013). Convergence in industrial relations institutions: The emerging AngloAmerican model? Industrial and Labor Relations Review, 66, 1045-1075.

Cooke, F. L. (2016). Employment relations in China. In G. J. Bamber, R. D. Lansbury, N. Wailes, \& C. F. Wright (Eds.), International and Comparative Employment Relations: National Regulation, Global Changes (6th edn). London: SAGE.

Crouch, C. (2005). Capitalist diversity and change: Recombinant governance and institutional entrepreneurs. Oxford: Oxford University Press.

Deeg, R., \& Jackson, G. (2007). Towards a more dynamic theory of capitalist variety. Socio-Economic Review, 5 , $149-179$.

Dupuis, M. (2017). International and comparative employment relations: Assessing the global, national and local level contributions to the field of CER. Employee Responsibilities and Rights Journal, 29, 151-157.

Edwards, P. K., Sánchez-Mangas, R., Tregaskis, O., et al. (2013). Human resource management practices in the multinational company: A test of system, societal, and dominance effects. Industrial and Labor Relations Review, 66, 588-617.

Estevez-Abe, M. (2006). Gendering the varieties of capitalism: A study of occupational segregation by sex in advanced industrial societies. World Politics, 59, 142-175.

Farivar, C. (2015). Two more startups sued as part of ongoing employee vs. contractor debate, ArsTechnica.Com, 25 September.

Frege, C., \& Godard, J. (2014). Varieties of capitalism and job quality: The attainment of civic principles at work in the United States and Germany. American Sociological Review, 79, 942-965.

Frege, C., \& Kelly, J. (Eds.). (2004). Varieties of unionism: Strategies for union revitalisation in a Globalising economy. Oxford: Oxford University Press.

Gereffi, G., Humphrey, J., \& Sturgeon, T. (2005). The governance of global value chains. Review of International Political Economy, 12, 78-104.

Goergen, M., Brewster, C., Wood, G., \& Wilkinson, A. (2012). Varieties of capitalism and investments in human capital. Industrial Relations, 51, 501-527.

Hall, P. A., \& Soskice, D. (Eds.). (2001). Varieties of capitalism: The institutional foundations of comparative advantage. New York: Oxford University Press.

Hancke, B., Rhodes, M., \& Thatcher, M. (2007). Introduction: Beyond varieties of capitalism. In B. Hancke, M. Rhodes, \& M. Thatcher (Eds.), Beyond varieties of capitalism: Conflict, contradictions and complementarities in the European economy (pp. 3-38). Oxford: Oxford University Press.

Harcourt, M., \& Wood, G. (2007). The importance of employment protection for skill development in coordinated market economies. European Journal of Industrial Relations, 13, 141-159.

Hassel, A. (2014). The paradox of liberalization-Understanding dualism and the recovery of the German political economy. British Journal of Industrial Relations, 52, 57-81.

Heery, E., Gooberman, L., \& Hauptmeier, M. (2017). The petroleum driver passport scheme: A case study in regulation. Industrial Relations Journal, 48, 274-291.

Howell, C. (2003). Varieties of capitalism: And then there was one? Comparative Politics, 36, 103-124.

Jackson, E., Looney, A., \& Ramnath, S. (2017). The rise of alternative work arrangements: Evidence and implications for tax filing and benefit coverage, Office of tax Analysis Working Paper 114. Washington, DC: US Department of the Treasury.

Katz, H. C., \& Colvin, A. J. S. (2016). Employment relations in the United States. In G. J. Bamber, R. D. Lansbury, N. Wailes, \& C. F. Wright (Eds.), International and Comparative Employment Relations: National Regulation, Global Changes (6th edition). London: SAGE.

Katz, H. C., \& Darbishire, O. (2000). Converging divergences: Worldwide changes in employment systems. Ithaca: Cornell University Press.

Katz, H. C., \& Wailes, N. (2014). Convergence and divergence in employment relations. In A. Wilkinson, G. Wood, \& R. Deeg (Eds.), The Oxford handbook of employment relations: Comparative employment systems (pp. 42-61). Oxford: Oxford University Press.

Keller, B. K., \& Kirsch, A. (2016). Employment relations in Germany. In G. J. Bamber, R. D. Lansbury, N. Wailes, \& C. F. Wright (Eds.), International and Comparative Employment Relations: National Regulation, Global Changes (6th edition). London: SAGE.

Kuo, K., Bao, A., Parker, E., \& Custer, C. (2016). Was Uber's China exit a failure or a success? Foreign Policy, august 4, foreignpolicy.Com. Accessed 13 August 2017.

Lakhani, T., Kuruvilla, S., \& Avgar, A. (2013). From the firm to the network: Global value chains and employment relations theory. British Journal of Industrial Relations, 51, 440-472.

Lansbury, R. D., \& Wailes, N. (2008). Employee involvement and direct participation. In P. Blyton, N. Bacon, J. Fiorito, \& E. Heery (Eds.), Sage handbook of industrial relations (pp. 434 446). London: SAGE. 
Lee, B. H. (2016). Employment relations in South Korea. In G. J. Bamber, R. D. Lansbury, N. Wailes, \& C. F. Wright (Eds.), International and Comparative Employment Relations: National Regulation, Global Changes (6th edition). London: SAGE.

Leggett, C. J. (2017). Book review: International and comparative employment relations: National regulation, global changes. Asia Pacific Journal of Human Resources, 55, 375-379.

Locke, R. M., Rissing, B. A., \& Pal, T. (2013). Complements or substitutes? Private codes, state regulation and the enforcement of labour standards in global supply chains. British Journal of Industrial Relations, 51, 519-552.

Madsen, J. S., Due, J., \& Andersen, S. K. (2016). Employment relations in Denmark. In G. J. Bamber, R. D. Lansbury, N. Wailes, \& C. F. Wright (Eds.), International and Comparative Employment Relations: National Regulation, Global Changes (6th edition). London: SAGE.

Manyika, J., Lund, S., Bughin, J., Robinson, K., Mischke, J., \& Mahajan, D. (2016). Independent work: Choice, necessity and the gig economy. San Francisco: McKinsey Global Institute.

Marchington, M., Grimshaw, D., Rubery, J., \& Willmott, H. (Eds.). (2005). Fragmenting work: Blurring organizational boundaries and disordering hierarchies. Oxford: Oxford University Press.

Martin, R., \& Bamber, G. J. (2004). International comparative employment relations theory: Developing the political economy perspective. In B. E. Kaufman (Ed.), Theoretical perspectives on work and the employment relationship (pp. 293-320). Illinois: Industrial Relations Research Association.

Meardi, G., \& Marginson, P. (2014). Global labour governance: Potential and limits of an emerging perspective. Work, Employment and Society, 28, 651-662.

Murad, A., \& Hook, L. (2015). Uber's International expansion chief steers for the exit after regulatory blows. Financial Times, 22 October, p. 14.

Ng, S. H. (2017). 'Employment across markets or nations': A review paper on International and Comparative Employment Relations. Employee Responsibilities and Rights Journal, 29, 165-171.

Poon, T. S., \& Ng, C. W. (2017). Beyond varieties of capitalism: Implications of global political changes and the emerging shared economy for comparative and international employment relations. Employee Responsibilities and Rights Journal, 29, 159-164.

Pudelko, M., \& Harzing, A. W. (2008). The golden triangle for MNCs: Standardization towards headquarters practices, standardization towards global best practices and localization. Organizational Dynamics, 37, $394-404$.

Ruggie, J. G. (2013). Just business: Multinational corporations and human rights. New York: WW Norton \& Company.

Ryder, G. (2015). The International Labour Organization: The next 100 years. Journal of Industrial Relations, 57, 748-757.

Sanders, D. E., \& Pattison, P. (2016). Worker characterization in a gig economy viewed through an Uber centric lens. Southern Law Journal, 26, 297-320.

Schmidt, V. (2002). The futures of European capitalism. Oxford: Oxford University Press.

Smith, C., \& Meiksins, P. (1995). System, society and dominance effects in cross-national organisational analysis. Work, Employment \& Society, 9, 241-267.

Sprague, R. (2015). Worker (mis)classification in the sharing economy: Trying to fit square pegs into round holes. ABA Journal of Labor \& Employment Law, 31, 53-76.

Streeck, W., \& Thelen, K. (2005). Introduction. In W. Streeck \& K. Thelen (Eds.), Beyond continuity: Institutional change in advanced political economies (pp. 1-39). Oxford: Oxford University Press.

Suzuki, H., Kubo, K., \& Ogura, K. (2016). Employment relations in Japan. In G. J. Bamber, R. D. Lansbury, N. Wailes, \& C. F. Wright (Eds.), International and Comparative Employment Relations: National Regulation, Global Changes (6th edition). London: SAGE.

Thelen, K. (2014). Varieties of liberalization and the new politics of social solidarity. New York: Cambridge University Press.

Wailes, N. (2016). How Indonesia's GoJek is beating Uber. Jakarta Post, 26 November 26, 7.

Wailes, N., Lansbury, R. D., Kitay, J., \& Kirsch, A. (2008). Globalization, varieties of capitalism and employment relations in the automotive assembly industry. In R. Blainpain \& R. D. Lansbury (Eds.), Globalization and employment relations in the auto assembly industry: A study of seven countries (pp. 1-11). Alphen aan den Rijin: Kluwer.

Wright, C. F. (2012). Immigration policy and market institutions in liberal market economies. Industrial Relations Journal, 43, 110-136.

Wright, C. F. (2016). Leveraging reputational risk: Sustainable sourcing campaigns for improving labour standards in production networks. Journal of Business Ethics, 137, 195-210.

Wright, C. F. (2017). Employer organizations and labour immigration policy in Australia and the United Kingdom: The power of political salience and social institutional legacies. British Journal of Industrial Relations, 55, 347-371.

Wright, C. F., \& Kaine, S. (2015). Supply chains, production networks and the employment relationship. Journal of Industrial Relations, 57, 483-501.

Wright, C. F., \& Lansbury, R. (2014). Trade unions and economic reform in Australia, 1983-2013. Singapore Economic Review, 59, 1-22. 